\title{
Revealing Students' Identity through the Way of Speaking
}

\author{
Mashabi Umar F. \\ Universitas Negeri Surabaya \\ Surabaya, Indonesia \\ mashabifatra@mhs.unesa.ac.id
}

\author{
Ayunita Leliana \\ Universitas Negeri Surabaya \\ Surabaya, Indonesia \\ ayunitaleliana@unesa.ac.id
}

\begin{abstract}
This paper aims to figure out the speakers say that indicate their regional origin, language elements that contribute their dialect, and students' feeling when they join a multilanguage community. To conduct this research, this paper uses two approaches, namely asking questions, and taking notes. The subject of this research is English Literature 2015 major, A class students in English Department, State University of Surabaya. In Indonesia, especially in East Java, most of university students come from various regions. They bring different ways of speaking. The way they choose the words and their accent are two things that are observable. In linguistics study, by knowing the way of someone's speaking, it may reveal the speaker's identity. This paper concludes that to reveal students' identity, the listener must pay attention to their dialect, which consists of grammar, vocabulary, and accent. By focusing on the elements, the listener can reveal students' identity easily.
\end{abstract}

\section{Keywords—speaking; university students; identity; dialect}

\section{INTRODUCTION}

People commonly define university as the highest education institution. University is the next step for students after graduating from senior high school. It is open for any students who want to continue their study to a higher stage. In addition, entering university is a crucial thing for new graduating students. They have some considerations to choose right university. Usually, students who want to continue their study to university absolutely will choose a great quality university. They will not think much about the location of the university as long as they get the best university. In consequence, mostly a good university has students who come from various regions; for example, Universitas Negeri Surabaya (UNESA) one of state universities in Surabaya. There are many students who come from various regions. Based on a survey that took at A class of English Literature 2015, the researcher reveals their origin for the first time. As the result, mostly they come from East Java, but they are not from Surabaya, such as Nganjuk, Kediri, Gresik, Sidoarjo, etc.

Students of different regions have their own unique languages. Mostly, they speak using the Javanese language as their daily communication. Even though most of them speak in the same language, Javanese; yet there must be a thing that can be identified as difference, such as their dialect. Dialects are linguistic varieties which are distinguishable by their vocabulary, grammar, and pronunciation; the speech of people from different social, as well as regions, groups may differ in these ways[1].

There are many studies that relate in the field of speaking; such as Spoken Language Identification with Phonotactics Methods on Minangkabau, Sundanese, and Javanese Languages[2], Two stages emotion recognition based on speaking rate[3], Understanding social variation in cardiovascular risk factors in women and men: the advantage of theoretically based measures[4], etc. This paper is the first research in the field of speaking to reveal people's identity through the way of speaking in the Javanese Language, especially in East Java. Actually, there are many studies that are relate to social background study; for example, Regional and social dialect. Holmes focuses more on English languages and society in general context, while this present research focuses on students of UNESA, especially for them who uses the Javanese language. In addition, this paper discusses the speakers say that indicate their regional origin, language elements that contribute their dialect, and what a feeling when they join a multi-language community.

\section{LITERATURE REVIEW}

\section{A. Javanese Language}

Indonesia is an archipelago country that has around 13.000 islands and about 220 million people[5]. Java is the most famous island, also mostly Indonesia citizen live there. Javanese language, hence, becomes a language that is mostly spoken. Javanese is spoken by about 65 million people and considered the thirteenth most widely spoken language in the world[6]. Javanese language is divided into three classes and each class has its own subclasses, such as;

1. Basa Jawa Ngoko;

Usually, it is used by teenagers who talk to their close friend, or when someone talks to other people who are younger than him. Moreover, Basa Jawa Ngoko is not appropriate to be used by a teenager when he wants to talk to someone older. Based on Javanese culture, when a teenager talks to older or his parents by using Basa Jawa Ngoko, it means he is not polite. Ngoko can be interpreted as familiar or informal[5]. Certainly, it is used in a conversation among teenagers or they are in 
same age, or an older to younger. Basa Jawa Ngoko is divided into 2 parts, i.e. Ngoko Lugu and Ngoko Andhap.

2. Basa Jawa Madya;

It is another kind of Javanese language that is higher than Jawa Ngoko. Furthermore, it can be known as the opposite of Jawa Ngoko. It seems how Basa Jawa Madya is used by a younger to older, or a student to a teacher, or a child to parents. Rarely, a teenager uses Basa Jawa Madya when he talks to his friend because it fits to be used by a younger to older, especially his parents or his teacher. Basa Jawa Madya is divided into 5 subs, they are Madya Ngoko, Madyantara, Madya karma, Mudha Krama, and Kramantara

3. Basa Jawa Krama;

It is the highest class of basa Jawa, especially Krama Inggil. It is used by old people to talk to older people or usually used to show a respect to others. Basa Jawa Krama are classified into Krama Lugu, Mudha Krama, Wredha Krama, Krama Inggil, Krama Desa, and Basa Kedathon.

There are three levels which are used in everyday conversation: Ngoko (low), Madya (medium), and Krama (high). Basa Jawa Ngoko is the indicator that is analyzed because students exactly use Jawa Ngoko as their daily conversation. When they are talking to their friends using the Javanese language. Surely, their language concerns 3 elements; such as grammar, vocabulary, and dialect.

\section{B. Grammatical Analysis}

Every language in the world has a structure or rule. By having a rule or structure in a language, it can be useful to help someone constructs a sentence or to communicate with others. Furthermore, one person can learn foreign language except for his origin language. Grammar is simply the word for the rules that people follow when they use a language; without rules, we would not be able to communicate with other people[7]. Absolutely, in the Javanese language, there is a grammatical rule which is shown by using a syntactic method. Syntax is a study which deals with a structure in a sentence[8]. In addition, syntax has some categories in a sentence, or it can be known as the part of speech; such as; noun, verb, adjective, preposition, adverb, and determiner.

1. Jawa; Arek iku mangan sego jagung.

a. $\left[{ }^{\mathrm{S}}\left[{ }^{\mathrm{NP}}\right.\right.$ Arek iku $]\left[{ }^{\mathbf{V P}}\left[{ }^{\mathbf{V}}\right.\right.$ mangan $]\left[{ }^{\mathrm{NP}}\right.$ sego jagung $\left.]\right]$

b. [ ${ }^{\mathrm{S}}\left[{ }^{\mathrm{NP}}\right.$ Arek iku] [ ${ }^{\mathrm{V}}$ mangan] [ ${ }^{\mathrm{NP}}$ sego jagung]

English; The boy eats corn rice.

a. $\left[{ }^{\mathrm{S}}\left[{ }^{\mathrm{NP}}\right.\right.$ The boy $]\left[{ }^{\mathrm{VP}}[\mathrm{V}\right.$ eats $]\left[{ }^{\mathrm{NP}}\right.$ corn rice $]$

b. $\left[{ }^{\mathrm{S}}\left[{ }^{\mathrm{NP}}\right.\right.$ the boy] $\left[{ }^{\mathrm{V}}\right.$ eats] [ ${ }^{\mathrm{NP}}$ corn rice]
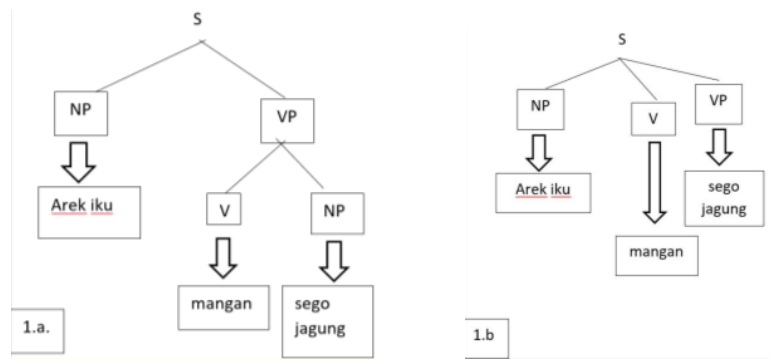

2. Javanese; Bocah kuwi mangan sega jagung

a. [ [ $\left[{ }^{\mathrm{S}}\right.$ Bocah kuwi] [ ${ }^{\mathrm{VP}}\left[{ }^{\mathrm{V}}\right.$ mangan] [ ${ }^{\mathrm{NP}}$ sega jagung]

b. $\left[{ }^{\mathrm{S}}\left[{ }^{\mathrm{NP}}\right.\right.$ Bocah kuwi] [ ${ }^{\mathrm{V}}$ mangan] $\left[{ }^{\mathrm{NP}}\right.$ sega jagung]

English; the boy eats corn rice.

a. $\left[{ }^{\mathrm{S}}\left[{ }^{\mathrm{NP}} \mathrm{The}\right.\right.$ boy $]\left[{ }^{\mathrm{VP}}\left[{ }^{\mathrm{V}}\right.\right.$ eats $]\left[{ }^{\mathrm{NP}}\right.$ corn rice $]$

b. $\left[{ }^{\mathrm{S}}\left[{ }^{\mathrm{NP}} \mathrm{The}\right.\right.$ boy $]\left[{ }^{\mathrm{V}}\right.$ eats $]\left[{ }^{\mathrm{NP}}\right.$ corn rice $]$

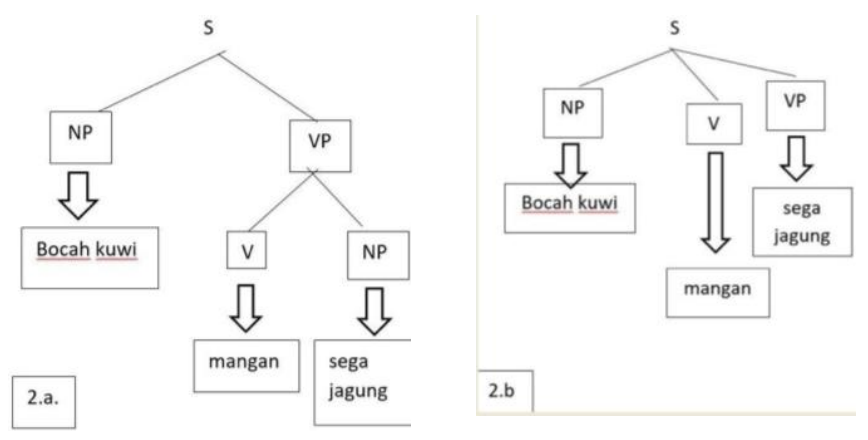

Tree diagrams $\{1\}$ and $\{2\}$ are the examples of the Javanese language. The researcher gives boxes which are filled with the Javanese language structures. They have the same grammatical rule which consists of subject, verb, and object. In morphology and syntax studies, phrases can be considered as a sentence if they consist at least a subject and a verb. By putting those four boxes of examples, the researcher tries to give information that Javanese structures that are usually used by students have the same structures. They just have a difference in using vocabulary (see $\{1 \mathrm{a}\}$ uses 'arek iku', while in $\{2 \mathrm{a}\}$ uses 'bocah kuwi').

\section{Vocabulary}

Vocabulary may be considered as the language element which has an important role in a language. It deals with a list of words. If there's no vocabulary, there's no language. Truly, without vocabulary, there will be no sentence, no text, and no language. Vocabulary is central to language and of crucial importance to the common language learner[9]. In addition, vocabulary is not only important role in language but also it is important to reveal someone's identity; such as regional. Vocabulary identifies as the diversity in regional which happens in the English language. New Zealand and England are different countries which use the English language as their national language. To identify a person who is from England or New Zealand, he can be identified how the way he uses the word in his language; for example, while people in England call them single parents, and New Zealanders call them solo parents[1]. In the Javanese language also happens the differences in the usage of vocabularies. 
Based on the survey that took at A class of English Literature 2015, the usage of vocabulary can be an indicator of students' regional, see table 1.

TABLE 1 DIFFERENCES OF VOCABULARIES BASED ON THE REGIONS

\begin{tabular}{|c|c|c|}
\hline \multicolumn{2}{|c|}{ Words based on the regions } & Explanations \\
\hline $\begin{array}{l}\text { Arek or rek } \\
\text { (Surabaya, Sidoarjo, } \\
\text { Jombang, } \\
\text { Mojokerto) }\end{array}$ & $\begin{array}{l}\text { Bocah or cah } \\
\text { (Nganjuk, Kediri, } \\
\text { Tuban, Bojonegoro, } \\
\text { Tuban) }\end{array}$ & $\begin{array}{ll}\text { a. } & \text { To call } \\
& \text { friends } \\
& \text { without } \\
& \text { mentioning } \\
& \text { his or her } \\
& \text { name. } \\
\text { b. 'you guys' }\end{array}$ \\
\hline $\begin{array}{l}\text { Iku } \\
\text { (Surabaya, Sidoarjo, } \\
\text { Jombang, } \\
\text { Mojokerto) }\end{array}$ & $\begin{array}{l}\text { Kuwi, kae } \\
\text { (Nganjuk, Kediri, } \\
\text { Tuban, Bojonegoro, } \\
\text { Tuban) }\end{array}$ & $\begin{array}{ll}\text { a. } & \text { To show a } \\
\text { thing that is } \\
\text { near } \\
\text { b. That }\end{array}$ \\
\hline $\begin{array}{l}\text { Suwene } \\
\text { (Surabaya) }\end{array}$ & $\begin{array}{l}\text { Suwine } \\
\text { (Nganjuk) }\end{array}$ & 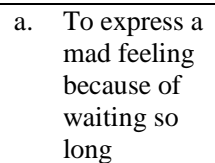 \\
\hline $\begin{array}{l}\text { Enggak } \\
\text { (Surabaya) }\end{array}$ & $\begin{array}{l}\text { Ora } \\
\text { (Nganjuk, Kediri, } \\
\text { Tuban, Bojonegoro, } \\
\text { Tuban) }\end{array}$ & a. $\quad$ No \\
\hline $\begin{array}{l}\text { Kon } \\
\text { (Surabaya, Sidoarjo, } \\
\text { Jombang, } \\
\text { Mojokerto) }\end{array}$ & $\begin{array}{l}\text { Kowe } \\
\text { (Nganjuk, Kediri, } \\
\text { Tuban, Bojonegoro, } \\
\text { Tuban) }\end{array}$ & You \\
\hline $\begin{array}{l}\text { Ote-ote } \\
\text { (Surabaya, Sidoarjo, } \\
\text { Jombang, } \\
\text { Mojokerto) }\end{array}$ & $\begin{array}{l}\text { Wechi } \\
\text { (Kediri) }\end{array}$ & $\begin{array}{ll}\text { a. } & \text { Traditional } \\
\text { meal }\end{array}$ \\
\hline $\begin{array}{l}\text { Wulan } \\
\text { (Surabaya, Sidoarjo, } \\
\text { Jombang, } \\
\text { Mojokerto) }\end{array}$ & $\begin{array}{l}\text { Sasi } \\
\text { (Tulungagung, } \\
\text { Semarang) }\end{array}$ & a. Month \\
\hline $\begin{array}{l}\text { Ngancani } \\
\text { (Surabaya, Sidoarjo, } \\
\text { Jombang, } \\
\text { Mojokerto) }\end{array}$ & $\begin{array}{l}\text { Baturi } \\
\text { (Nganjuk, Kediri, } \\
\text { Tuban, Bojonegoro, } \\
\text { Tuban) }\end{array}$ & $\begin{array}{ll}\text { a. Accompan } \\
\mathrm{y}\end{array}$ \\
\hline $\begin{array}{l}\text { Pancet / tetep } \\
\text { (Surabaya, Sidoarjo, } \\
\text { Jombang, } \\
\text { Mojokerto) }\end{array}$ & $\begin{array}{l}\text { Panggah } \\
\text { (Nganjuk, Kediri, } \\
\text { Tuban, } \\
\text { Bojonegoro,Tulungag } \\
\text { ungTuban) }\end{array}$ & $\begin{array}{ll}\text { a. } & \text { Remain the } \\
\text { same }\end{array}$ \\
\hline $\begin{array}{l}\text { Yaopo } \\
\text { (Surabaya, Sidoarjo) }\end{array}$ & $\begin{array}{l}\text { Piye } \\
\text { (Nganjuk, Jombang, } \\
\text { Mojokerto, Kediri, } \\
\text { Tuban, Bojonegoro, } \\
\text { Tuban, Tulungagung) }\end{array}$ & a. How \\
\hline
\end{tabular}

\section{Accent}

Accent is one of language elements which deals with sounds of words. We can concern with how people pronounce words to distinguish people based on their region. Furthermore, each region has its own accent. Although they use the same word but the way they pronounce it is different. East Java is divided into several regions; such as Surabaya,
Jombang, Nganjuk, Kediri, Tuban etc. Mostly each of its residences is using the Javanese language. Although they speak the same language, there must be a thing that can be identified as the difference; such as accent. In addition, accent also deals with phonology, a study which refers to pronounce a word. Regional differences in phonology occur when speakers from different regions make a different number of phonemic contrasts[10]. Phonemic deals with symbols that occur in a dictionary or in a book which focuses on phonology or pronunciation study; for example, the word 'cat' is separated into three distinct phonemes, /k/, /æ/, /t/. The Javanese language also has its own phonemic symbol. Traditional analysis of the Javanese vowel inventory claims that Javanese has eight vowel phonemes: 6 phonemes and 2 additional pairs The current study sets to extends those of Fagan (1988), Hayward (1993, 1995) and Thurgood (2004) by investigating Javanese vowels /i/, /e/, /a/, /a/, /u/ and /o/ (Dudas 1976; Nothofer 2009; Clynes 1995), (Perwitasari, 2017)[6]. Furthermore, this section shows some sentences produced by 2 different people who each is from different regionals. In addition, each conversation of them includes the phonemic transcription.

1. English; I have eaten fried rice Aku mau mangan sego goreng

a. /aku//mau//man'an//sego/ /gor'ey/

b. /aku//mau//may'an /seghou//ghour'ey/

Sentences $1 \mathrm{a}$ and $1 \mathrm{~b}$ are almost the same. Unfortunately, there is a little bit difference which occurs in the phonemic transcription of $[\mathrm{g}]$ and [o]. In 1a, interprets the speaker is form Surabaya, while, in $1 \mathrm{~b}$, the speaker is from Nganjuk. The phrase 'sego goreng' is the same phrase which used in both city. In contrast, the way they pronounce is different. In Surabaya, phoneme $/ \mathrm{g} / \mathrm{as}[\mathrm{g}]$ and $/ \mathrm{o} /$ as [o], while people who originally from Nganjuk pronounce /gh/ as [gh] and /ou/ as [o]. /gh/ in $1 \mathrm{~b}$ has more voice while /g/ in 1a is less. In the same case $/ 0 /$ in $1 \mathrm{a}$ is short, while the [o] as in $1 \mathrm{~b}$ is little bit longer /ou/.

2. English; Joni wears white t-shirt Joni gawe klambi putih

a. /djoni//gawe/ /klambi//putih/

b. /djoni /gawe//klambi//put'ie'h/

$2 \mathrm{a}$ indicates the speaker from Sidoarjo, while in $2 \mathrm{~b}$ the speaker is from Madura. The difference occurs in phonemes [t] and [i]. Madurese has strong accent, because Madurese has its own language and accent. When they speak in Javanese, they can be identified easily. Madurese has strong stress when they pronounce phoneme [t] as $/ \mathrm{t}^{\prime} /$ and long /ie/ as [i]. While Sidoarjonese pronounce [t] and [i] as usual, less stress and shorter.

\section{METHOD}

To achieve real evidence, this research was conducted in UNESA, Surabaya, especially at English Department. The subject of the research was A class of English Literature students. Data is collected qualitatively by doing interview, 
observations, and questionnaires through the subjects. The next step was selecting then analyzing the data. Finally, it becomes the evidence to support the theory chosen.

\section{RESUlT AND DISCUSSION}

For the first time when students became freshmen, they absolutely wanted to make new friends. They usually asked some questions about their friends' identities; such as hometown, current address, previous school, etc. Additionally, the question about hometown is the question that mostly is asked. The data that was taken in A class of English Literature 2015, shows that the question about hometown is the most popular question. The following pie-chart shows questions commonly asked among freshmen.

\section{POPULAR QUESTION AMONG FRESHMEN}

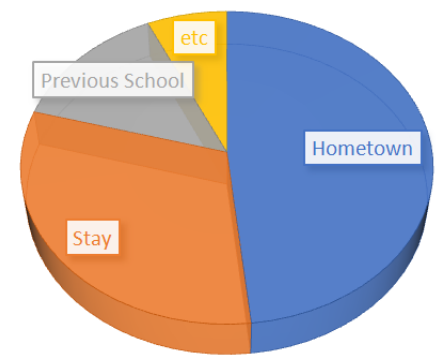

Fig 1. Percentage of each question among freshmen

Regarding the percentage, this paper aims to reveal students' identity through the way of speaking, especially their hometown. After asking the question, the researcher finds uniqueness that reveals their identity. It answers the first research question, "What do the speakers say that indicate their regional origin?" When people are talking to others, they can know their interlocutors' regional origin by paying attention to language elements; such as grammar, vocabulary, and accent.

This language elements relate to the second question "what are language elements that contribute their dialect?" Based on the Holmes' book, social dialect consists of grammar, vocabulary and accent or pronunciation[1]. To reveal someone's regional, at least, vocabulary can be identified as the indicator of difference. There are vocabulary differences in the varieties spoken in different regions too[1]. Moreover, not only vocabulary that is important to reveal someone's identity but other aspects are also important; such as grammar and accent. This paper provides some data to answer the second question that was conducted at A class of English literature 2015. The data consist of some utterances that were spoken by some students.

English; I eat the spicy fried rice.

a. Utterance 1;aku mangan sego gorengpedesbanget.

[ ${ }^{\mathrm{S}}\left[{ }^{\mathrm{NP}} \mathrm{aku}\right]\left[{ }^{\mathrm{VP}}\left[{ }^{\mathrm{V}}\right.\right.$ mangan] [ ${ }^{\mathrm{NP}}$ sego goreng] [ ${ }^{\mathrm{AP}}$ pedes banget $\left.]\right]$ /aku/ /manan/ /segho//gho'rey/ /pedes/ /bhayet/

b. Utterance 2; aku mangan sego gorengpedesseru. $\left[{ }^{\mathrm{S}}\left[\mathrm{NP}^{\mathrm{N}} \mathrm{aku}\right]\left[{ }^{\mathrm{VP}}\left[{ }^{\mathrm{V}}\right.\right.\right.$ mangan $]\left[{ }^{\mathrm{NP}}\right.$ sego goreng $]\left[{ }^{\mathrm{AP}}\right.$ pedes seru $\left.]\right]$ /aku//manan//sego//gorey//pedes//seru/

Both utterances consist of all language element; such as grammar, vocabulary, and accent. The first and the second grammar have the same grammatical rule. In fact, all Javanese language has the same grammatical rule, no matter where Javanese people is from, they still use the same grammatical rule. To reveal someone's identity by paying attention to his grammar structural only is not enough, so other elements are also important; such as vocabulary and accent. In the first utterance and second, there is a different word in each utterance. The first uses "banget" and the second uses "seru". The meaning of each of these words is to explain more about 'pedes'. In English, these different words mean "too". The usage of each word represents the regional. Based on the data that was collected, the usage of "banget" is mostly used by students who come from Nganjuk, Kediri, Tuban and Tulungagung, while the usage of "seru" word is mostly used by students who come from Gresik. In addition, another language element can support that dialect can identify someone's regional such as accent. In the first and second utterance show that not only vocabulary is different, but the accent of each utterance also. The differences happen in same words [sego goreng], but each utterance pronounces the words differently. The first utterance pronounces /seghogho'rey/ as [sego goreng]. While the second utterance pronounce /sego gorey/. Mostly, students are from Kediri, Nganjuk, Tuban, and Tulungagung pronounce $/ \mathrm{gh} / \mathrm{as}[\mathrm{g}]$. They put more stress on the word, while students from Surabaya, Sidoarjo, Gresik, Mojokerto, and Jombang pronounce /g/ as [g].

The third research question is "what do the speakers feeling toward their dialect or accent?". University is universal education institution. Every student can continue the study to university, no matter where he is from a long as he could pass the selection. In consequence, in university, there are many multilingualism communities which means a community that consists of people who are from various regions. A class of English Literature 2015 can be considered as multilingualism community. According to the data, new students in university firstly the thing that they do is to make friends. The thing that they must do to make a friend is they must speak to other friends. Mostly they still bring the origin part of their languages such as dialect or accent. They also feel confident to speak by using their own uniqueness of their language because it's a thing that indicates their identity. In the same case, this community among new students in university become a multilanguage community.

According to Holmes J. [1] differentiation in using dialect is caused by their own regions, although they are in the same community. At a community, named class A academic year 2015 of English Department, some students are from various regions. Most students who are from Surabaya use 'banget' to express something more, while students who are from Gresik use "seru'. Both "banget" and "seru" mean "too" in English. Moreover, each region has its own accent, for instance students who are from Surabaya apply different accent from students who are from Nganjuk or Kediri when they pronounce /g/ and 
/d/. Surabaya students will produce $/ \mathrm{g} /$ as $[\mathrm{g}]$ and $/ \mathrm{d} /$ as $[\mathrm{d}]$ which means they pronounce those sounds in normal way, meanwhile Nganjuk or Kediri students will pronounce /g/ as [gh] and /d/ as [dh] which means they put more stress when they produce them.

\section{CONCLUSION}

To reveal someone's identity can be done by everyone, especially university students. When they become freshmen and want to reveal their friends' identity; such as their region. They can pay attention to their dialect or language elements; such as grammar, vocabulary, and accent. These elements contribute to revealing students' identity. In the Javanese language, most of the speakers use the same grammatical rule. In consequence, by paying attention to the grammar only is difficult to reveal their identity. Other elements must be watched also; such as vocabulary and accent. Each region must have some different vocabularies that identify as its region. The difference in vocabulary can be an indicator to reveal students' identity. In addition, the way students pronounce words also can be identified to reveal students' identity. Literally, every regional must have its own accent. Although, the words are same, every people in different regions may pronounce them differently. At last, by watching students' dialect or language elements can help students to reveal other students' identity.

\section{REFERENCES}

[1] P. Wolff and K. J. Holmes, "Linguistic relativity," Wiley Interdiscip. Rev. Cogn. Sci., vol. 2, no. 3, pp. 253-265, 2011.

[2] N. E. Safitri, A. Zahra, and M. Adriani, "Spoken Language Identification with Phonotactics Methods on Minangkabau, Sundanese, and Javanese Languages," Procedia Comput. Sci., vol. 81, no. May, pp. 182-187, 2016.

[3] S. G. Koolagudi and R. S. Krothapalli, "Two stage emotion recognition based on speaking rate," Int. J. Speech Technol., vol. 14, no. 1, pp. 35-48, 2011.

[4] M. Bartley, A. Sacker, D. Firth, and R. Fitzpatrick, "Understanding social variation in cardiovascular risk factors in women and men: The advantage of theoretically based measures," Soc. Sci. Med., vol. 49, no. 6, pp. 831-845, 1999.

[5] Y. K. Kurniasih, "Gender, Class and Language Preference : A case study in Yogyakarta," Linguist. Progr., pp. 1-25, 2005.

[6] A. Perwitasari, M. Klamer, J. Witteman, and N. O. Schiller, "Quality of Javanese and Sundanese vowels," J. Southeast Asian Linguist. Soc., vol. 10, no. 2, pp. 1-9, 2017.

[7] R. K. Abdulmajeed and S. K. Hameed, "Using a Linguistic Theory of Humour in Teaching English Grammar," English Lang. Teach., vol. 10, no. 2, p. 40, 2017.

[8] A. McIntyre, "Fundamentals of English Syntax," no. Version 3, p. 41, 2014.

[9] C. Gao and B. Xu, "The Application of Semantic Field Theory to English Vocabulary Learning," Theory Pract. Lang. Stud., vol. 3, no. 11, pp. 2030-2035, 2013.

[10] R. I. Mcdavid, "Historical, Regional, and Social Variation," $J$. English Linguist., vol. 1, no. 1, pp. 25-40, 1967. 